\title{
Effect of Feeding Corn Gluten Meal in Feed Ration on Growth Performance of Commercial Broiler Chicken
}

\author{
K. Abhijeet, S.B. Prasanna', P.S. Mahesh, R.Y. Ranjith",
} Prabha Karan², S.K. Bhandekar $^{3}$, S.M. Ali', K.D. Masood ${ }^{1}$

10.18805/ajdfr.DR-1629

\begin{abstract}
Background: The productivity and profitability of commercial broiler largely depend on nutrition and growth performance and, therefore, this industry requires high quality protein sources, such as corn gluten meal (CGM). Many studies have been conducted on protein quality changes and other nutritional characteristics of CGM in several countries Corn gluten meal contains around $60 \%$ $\mathrm{CP}$ and is a byproduct of wet milling of corn, most of which is used for manufacture of high fructose corn syrup and corn flour. Being high in crude protein, it is often compared to animal protein ingredients during feed formulation. Thus, this study was intended to evaluate the effect of feeding corn gluten meal in feed ration on growth performance of commercial broiler chicken.

Methods: A feeding trial was conducted in the year 2018 with an objective to assess the effect of feeding corn gluten meals (CGM) in broiler chicken. Six hundred broiler chickens (day old) were randomly allotted to three groups, comprising of fifty broiler chickens in each treatment group with four replicates. The group-I $\left(T_{1}\right)$ broiler chicken were fed with composite diet containing $5 \%$ corn gluten meal where as group-II $\left(\mathrm{T}_{2}\right)$ received composite diets comprising of CGM $10 \%$. The group-III $\left(\mathrm{T}_{3}\right)$ served as control group with normal broiler diet. The experimental period lasted for six weeks. Weekly body weight and feed consumption were measured in each group.

Result: Diet composite of $10 \%$ of corn gluten meal had significantly $(P \leq 0.05)$ higher weight gain, lower feed intake and improved FCR than $T_{1}$ and $T_{3}$ group. CGM supplementation can be ideally improved broiler weight gain, feed consumption and FCR.

Key words: Broiler, Composite diet, Corn gluten meal, FCR, Weight gain.
\end{abstract}

\section{INTRODUCTION}

Corn gluten meal contains around $60 \% \mathrm{CP}$ and is a byproduct of wet milling of corn, most of which is used for manufacture of high fructose corn syrup and corn flour. Being high in crude protein, it is often compared to animal protein ingredients during feed formulation. The protein is merely a concentration of the original corn protein compound brought about by removal of the starch in the endosperm. Protein from corn gluten meal is composed mainly of zein $(68 \%)$, glutelin (27\%) and small amounts of globulins (1.2\%) (Cha et al., 2000). Gluten meal is also very high in Xanthophylls pigments (up to $300 \mathrm{mg} / \mathrm{g}$ ) and is a very common ingredient where there is a need to pigment poultry products using much more than $10 \%$. CGM causes visible increase in pigmentation of broilers and egg yolks (Leeson and Summer, 2005). It is, also, rich in Methionine (Sasse and Baker, 1973), but, its Arginine, lysine and tryptophan contents are rather low (Peter et al., 2000). Poultry industry in India needs high quality protein sources, such as CGM. Many studies have been conducted on protein quality changes and other nutritional characteristics of CGM in several countries (Sasse and Baker 1973; Peter et al. 2000; Kim et al. 2012) The nutrient profile of Corn gluten meal shown in (Table 1).

The trail was carried out with objectives to study the body weight gain and FCR of broiler chicken supplemented with CGM based diet. This trail would be helpful for feed technologist in formulating feed for profitable broiler farming.
Central Poultry Development Organization and Training Institute, Bangalore-560 088, Karnataka, India.

'Department of LPM, Veterinary College, Hebbal-560 024, Bangalore, Karnataka, India.

${ }^{2}$ First Class Veterinary Hospital, Girihinda Chowk, Sheikhpura811 105, Bihar, India.

${ }^{3}$ Livestock Officer, Central Cattle Breeding Farm, Bangalore-560 088, Karnataka, India.

Corresponding Author: Abhijeet Kumar, Central Poultry Development Organization and Training Institute, Hessarghatta, Bangalore-560 088, Karnataka, India.

Email: dr.abhikumar0501@gmail.com

How to cite this article: Abhijeet, K., Prasanna, S.B., Mahesh, P.S., Ranjith, R.Y., Karan, P., Bhandekar, S.K., Ali, S.M. and Masood, K.D. (2021). Effect of Feeding Corn Gluten Meal in Feed Ration on Growth Performance of Commercial Broiler Chicken. Asian Journal of Dairy and Food Research. 40(3): 337-340. DOI: 10.18805/ ajdfr.DR-1629.

Submitted: 20-01-2021 Accepted: 29-04-2021 Online:31-07-2021

\section{MATERIALS AND METHODS}

An experimental trail was conducted during the year 2018 at Central Poultry Development Organization and Training Institute, Bangalore, Karnataka, India to evaluate the effect of partial replacing corn gluten meal in the diet of commercial broiler on growth performance, feed conversion ratio and feed consumption. Six hundred broiler chickens (day old) 
Table 1: Nutrient profile of corn gluten meal.

\begin{tabular}{lc}
\hline Proximate principles & Proximate values \\
\hline CP (\%) & 60 \\
ME (Kcal/kg) & 3750 \\
EE (\%) & 2.51 \\
CF (\%) & 2.48 \\
Methionine (\%) & 1.61 \\
Lysine (\%) & 0.90 \\
Threonine (\%) & 1.70 \\
\hline
\end{tabular}

Leeson and summer (2005).

were randomly allotted to three groups, comprising of fifty broiler chickens in each treatment group with four replicates. They were placed in a commercial brooder at $33-34^{\circ} \mathrm{C}$ and given ad lib access to a standard chick starter and finisher feeds and provided water throughout the day in all period of the experiment. The initial room temperature was $33.5^{\circ} \mathrm{C}$ and this was reduced by $1^{\circ} \mathrm{C}$ at 2 -day intervals to $24^{\circ} \mathrm{C}$. The LED blue light with the light intensity of 10 lux provided throughout the experimental period. Basal diet was formulated using maize, soybean meal, de-oiled rice bran (DORB), corn gluten meal (CGM) and feed additives. The broiler starter and finisher rations were formulated as per BIS (2007). Starter mash was fed from day one to 21 days and finisher mash from 22 to 42 days. Ingredient and nutrient composition of experimental diets are given in (Table 2). The group-I $\left(T_{1}\right)$ Broiler chickens were fed with composite diet containing 5\% CGM where as group-II $\left(\mathrm{T}_{2}\right)$ received composite diets comprising of $10 \%$ CGM. The group-III $\left(\mathrm{T}_{3}\right)$ served as control group with normal broiler diet. The experimental period lasted for six weeks; Weekly body weight and feed consumption were measured in each group.

\section{Statistical analysis method}

The descriptive statistics for productive traits were analyzed using SPSS version 16.0. ANOAV one way was carried out to study the effect of feeding CGM in feed on growth performance and feed intake of commercial broiler chicken.

The following parameters were studied during the trial:

\section{Body weight}

The body weights (grams) of individual bird were recorded from $0^{\text {th }}$ day of age to till forty two days of age to monitor the pattern of body weight gain. The weighing of the birds was done in the early hours of the day before feeding by using digital weighing balance during the experimental period. The weights recorded were pooled and the data were analyzed.

\section{Feed consumption}

The average feed consumption (in grams) of each group was recorded from $0^{\text {th }}$ day of age to till forty two days of age to monitor the pattern of feed consumption. The weighing of the left over feed was done in the early hours of the day before feeding by using digital weighing balance during the experimental period. The weights recorded were pooled and the data were analyzed.

\section{Feed conversion ratio}

The cumulative FCR for the $T_{1}, T_{2}$ and $T_{3}$ (control group) were calculated with the mathematical formula:

$$
\begin{aligned}
& \text { Feed conversion ratio }(\mathrm{FCR})= \\
& \frac{\text { Total quantity of feed consumed per bird in } \mathrm{Kg}}{\text { Mean body weight gain in } \mathrm{Kg}}
\end{aligned}
$$

\section{RESULTS AND DISCUSSION}

Effect of inclusion of CGM in feed of commercial broilers on average body weight, body weight gain, feed consumption and FCR of three groups are given in (Table 3, 4 and 5).

\section{Average body weight}

On $7^{\text {th }}$ day, the average body weight (in grams) of $T_{1}, T_{2}$ and $\mathrm{T}_{3}$ groups were $175.50,178.50$ and 170.00 (Table 3 ), respectively. Whereas, the average body weight (in grams) at $14^{\text {th }}$ day of $T_{1}, T_{2}$ and $T_{3}$ groups were $460.25,466.75$ and 429.50 , respectively .There is significant increase $(P<0.05)$ in average body weight of $T_{2}$ group over $T_{1}$ and control group on replacement of 10 per cent corn gluten meal for the period $7^{\text {th }}$ and $14^{\text {th }}$ day. On $21^{\text {st }}$ day, the average body weight (in grams) of $T_{1}, T_{2}$ and $T_{3}$ groups were 856.50, 854.00 and 800.00 (Table 3), respectively. There is significant increase $(\mathrm{P}<0.05)$ in average body weight of $\mathrm{T}_{1}$ group over $\mathrm{T}_{2}$ and control group on replacement of 05 per cent corn gluten meal. Whereas, the average body weight (in grams) at $28^{\text {th }}$ day of $T_{1}, T_{2}$ and $T_{3}$ groups were $1443.25,1474.50$ and 1387.00 , respectively. There is significant increase $(P<0.05)$ in average body weight of $T_{2}$ group over $T_{1}$ and control group on replacement of 10 per cent corn gluten meal. On $35^{\text {th }}$ day, the average body weight (in grams) of $T_{1}, T_{2}$ and $T_{3}$ groups were 2032.75, 2074.25 and 1883.75 (Table 3), respectively. Whereas, the average body weight (in grams) at $42^{\text {nd }}$ day of $T_{1}, T_{2}$ and $T_{3}$ groups were $2623.75,2720.50$ and 2452.50, respectively. There is significant increase $(\mathrm{P}<0.05)$ in average body weight of $\mathrm{T}_{2}$ group over $\mathrm{T}_{1}$ and control group on replacement of 10 per cent corn gluten meal for the period $35^{\text {th }}$ and $42^{\text {nd }}$ day. In this experiment, increasing of CGM content in the diets had positive effect on weekly body weight gain. The result of the present study are in agreement with Sayedi and Ali. (2014) but Ismail et al. (2005) reported that increasing dietary CGM beyond $9 \%$ have no effect on broiler chicks' growth performance and weight gain reduced a little with increasing the CGM supplementation in diets. In previous studies, Waldroup (2000) studied that CGM could be included in broiler diets without impairing performance at rates of $10 \%$. In more recent studies that have evaluated the use of high levels of CGM in broilers diets, supplementation with liquid and dried CGM products had no negative effect on growth performance compared to control diets (Koreleski, 2003). 


\section{Feed consumption}

The average feed consumption (in grams) at the age of 42 days were recorded 4712,4680 and 4760 for $T_{1}, T_{2}$ and $T_{3}$ group (Table 4), respectively. Feed consumption of broilers was significantly affected $(P<0.05)$ due to supplementation of corn gluten meal in different proportions. This could be due to the imbalance amino acids especially lysine, methionine etc. content in the consumed feed which results in transmission of signals to satiety centre in brain, which leads to lower feed intake (Harper 1964). Peng et al. (1972) demonstrated that amino acid imbalance can reduce the consumption of lysine as the first limiting amino acid in broiler which causes a lower feed intake and reduce the broiler chicks' performance. However, in the present experiment, CGM containing diets were enriched or fortified with synthetic amino acids to reduce the effect of amino acid imbalance. The results of the present findings were partially agreement with the findings of Chamruspollert et al. (2002) who reported that the supplementation of the corn gluten meal will decrease the feed intake. However on contrary to Rose et al.
(2003) reported a significant increase in feed intake when broiler chicks were fed on diet containing 10\% CGM.

\section{Feed conversion ratio}

The FCR (Table 5) for the $T_{1}, T_{2}$ and $T_{3}$ were calculated with the mathematical formula and recorded 1.795, 1.720 and 1.940 , respectively at the end of the trial. Exceptionally, there is significant influence $(P<0.05)$ in average FCR $(1.720)$ of $T_{2}$ group over $T_{1}$ and $T_{3}$ control group on replacement of 10 per cent corn gluten meal in commercial feed of Broilers. The results of the present study are in agreement with Seyedi and Ali. (2014) who reported that there was remarkable improvement for FCR was observed in broilers chicks fed all levels of CGM during rearing weeks. The similar study conducted by Silva et al. (2003) who observed positive effect of CGM supplementation and reported that Feed Conversion Ratio improved with increasing supplementation of Corn gluten meal (Koreleski, 2003). However, in contrary to Ismail et al. (2005) reported that negative effect on FCR on supplementation with more than 9 per cent of CGM in commercial feed for broilers. Sayedi and Ali (2014)

Table 2: Composition (\%) of experimental diets (0-42 days).

\begin{tabular}{|c|c|c|c|c|c|c|}
\hline \multirow{2}{*}{ Ingredients (\%) } & \multicolumn{3}{|c|}{ 0-3 weeks (Starter) } & \multicolumn{3}{|c|}{ 4-6 weeks (finisher) } \\
\hline & $\mathrm{T}_{1}$ & $\mathrm{~T}_{2}$ & $\mathrm{~T}_{3}$ & $\mathrm{~T}_{1}$ & $\mathrm{~T}_{2}$ & $\mathrm{~T}_{3}$ \\
\hline Corn maize & 54 & 54 & 54 & 60 & 60 & 60 \\
\hline Soybean meal & 30 & 25 & 35 & 17.5 & 17.5 & 30 \\
\hline Corn gluten meal & 05 & 10 & - & 10 & 10 & - \\
\hline DORB & 7.5 & 7.5 & 7.5 & 08 & 08 & 7.5 \\
\hline Mineral mix & 2.5 & 2.5 & 2.5 & 2.5 & 2.5 & 2.5 \\
\hline Salt & 0.5 & 0.5 & 0.5 & 0.5 & 0.5 & 0.5 \\
\hline Vitamin mix & 0.5 & 0.5 & 0.5 & 0.5 & 0.5 & 0.5 \\
\hline \multicolumn{7}{|l|}{ Total } \\
\hline \multicolumn{7}{|c|}{ Chemical composition } \\
\hline Moisture (\%) & 90.2 & 90.5 & 91.2 & 90.8 & 90.6 & 90.3 \\
\hline $\mathrm{CP}(\%)$ & 22.18 & 22.93 & 22.15 & 20.15 & 20.15 & 20.5 \\
\hline EE (\%) & 3.5 & 3.5 & 3.8 & 4.0 & 4.0 & 3.25 \\
\hline CF (\%) & 3.42 & 3.40 & 3.8 & 3.8 & 3.8 & 3.6 \\
\hline ME (Kcal/kg) & 2910 & 2940 & 2908 & 2953 & 2953 & 2950 \\
\hline
\end{tabular}

* Mineral mixture: Contains calcium-32\%, phosphorus-6\%, copper 100 ppm, cobalt-60 ppm, manganese-2700 ppm, iodine-100 ppm, zinc-2600 ppm, iron-0.1\%. ${ }^{* *}$ Vit.AB2 D3 K: Per gram contains Vit. A-82, $500 \mathrm{IU}, \mathrm{D} 3-12,000 \mathrm{IU}, \mathrm{B} 2-50 \mathrm{mg}$ and K-10 mg. ${ }^{* * *} \mathrm{~B}-\mathrm{complex}$ : per gram contains Vit B1 -4 mg, B6 -8 mg, B12-40 mg, E-20 mg, Niacin-60 mg and calcium panthothenate-12.5.

Table 3: Effect of feeding corn gluten meal on average body weight (mean $\pm \mathrm{SE}$ ) in commercial broilers.

\begin{tabular}{lcrr}
\hline \multirow{2}{*}{ Age } & \multicolumn{3}{c}{ Average body weight $(\mathrm{g})$} \\
\cline { 2 - 4 } & $\mathrm{T}_{1}$ & $\mathrm{~T}_{2}$ & $\mathrm{~T}_{3}$ \\
\hline $0^{\text {th }}$ day & $40.87 \pm 0.23^{\mathrm{c}}$ & $40.87 \pm 0.51^{\mathrm{b}}$ & $41.25 \pm 0.32^{\mathrm{a}}$ \\
$7^{\text {th }}$ day & $175.50 \pm 1.75^{\mathrm{c}}$ & $178.50 \pm 0.64^{\mathrm{a}}$ & $170.00 \pm 1.05^{\mathrm{b}}$ \\
$14^{\text {th }}$ day & $460.25 \pm 9.21^{\mathrm{b}}$ & $466.75 \pm 6.02^{\mathrm{a}}$ & $429.50 \pm 3.44^{\mathrm{c}}$ \\
$21^{\text {th }}$ day & $856.50 \pm 22.37^{\mathrm{a}}$ & $854.00 \pm 11.96^{\mathrm{b}}$ & $800.00 \pm 9.20^{\mathrm{c}}$ \\
$28^{\text {th }}$ day & $1443.25 \pm 11.90^{\mathrm{b}}$ & $1474.50 \pm 7.90^{\mathrm{a}}$ & $1387 \pm 5.09^{\mathrm{c}}$ \\
$35^{\text {th }}$ day & $2032.75 \pm 31.69^{\mathrm{b}}$ & $2074.25 \pm 13.73^{\mathrm{a}}$ & $1883.75 \pm 4.90^{\mathrm{c}}$ \\
$42^{\text {nd }}$ day & $2623.75 \pm 35.20^{\mathrm{b}}$ & $2720.50 \pm 35.93^{\mathrm{a}}$ & $2452.50 \pm 42.56^{\mathrm{c}}$ \\
\hline
\end{tabular}

The means bearing different superscripts in rows differ significantly* $(\mathrm{P}<0.05)$. 
Effect of Feeding Corn Gluten Meal in Feed Ration on Growth Performance of Commercial Broiler Chicken

Table 4: Effect of feeding corn gluten meal on feed consumption grams \birdlweek (mean \pm SE) in commercial broilers.

\begin{tabular}{lccc}
\hline \multirow{4}{*}{ Age } & \multicolumn{3}{c}{ Feed consumption $(\mathrm{g})$} \\
\cline { 2 - 4 } & $\mathrm{T}_{1}$ & $\mathrm{~T}_{2}$ & $\mathrm{~T}_{3}$ \\
\hline $7^{\text {th }}$ day & $142 \pm 2.76^{\mathrm{a}}$ & $143 \pm 2.84^{\mathrm{b}}$ & $144 \pm 2.80^{\mathrm{c}}$ \\
$14^{\text {th }}$ day & $469 \pm 2.56^{\mathrm{b}}$ & $467 \pm 3.84^{\mathrm{a}}$ & $471 \pm 1.67^{\mathrm{c}}$ \\
$21^{\text {th }}$ day & $1086 \pm 9.48^{\mathrm{b}}$ & $1078 \pm 7.14^{\mathrm{a}}$ & $1101 \pm 6.84^{\mathrm{c}}$ \\
$28^{\text {th }}$ day & $1981 \pm 7.41^{\mathrm{b}}$ & $1971 \pm 15.54^{\mathrm{a}}$ & $1986 \pm 15.41^{\mathrm{c}}$ \\
$35^{\text {th }}$ day & $3412 \pm 17.89^{\mathrm{b}}$ & $3316 \pm 15.81^{\mathrm{a}}$ & $3483 \pm 20.44^{\mathrm{c}}$ \\
$42^{\text {nd }}$ day & $4712 \pm 13.96^{\mathrm{b}}$ & $4680 \pm 18.92^{\mathrm{a}}$ & $4760 \pm 19.33^{\mathrm{c}}$ \\
\hline
\end{tabular}

The means bearing different superscripts in rows differ significantly ${ }^{*}$ $(\mathrm{P}<0.05)$.

Table 5: Effect of feeding corn gluten meal on FCR (mean \pm SE) in commercial broilers.

\begin{tabular}{lccc}
\hline \multirow{2}{*}{ Age } & \multicolumn{3}{c}{$F C R$} \\
\cline { 2 - 4 } & $\mathrm{T}_{1}$ & $\mathrm{~T}_{2}$ & $\mathrm{~T}_{3}$ \\
\hline $7^{\text {th }}$ day & $0.809 \pm 0.03^{\mathrm{a}}$ & $0.817 \pm 0.04^{\mathrm{b}}$ & $0.847 \pm 0.01^{\mathrm{c}}$ \\
$14^{\text {th }}$ day & $0.981 \pm 0.04^{\mathrm{b}}$ & $0.999 \pm 0.03^{\mathrm{c}}$ & $0.911 \pm 0.03^{\mathrm{a}}$ \\
$21^{\text {th }}$ day & $1.267 \pm 0.05^{\mathrm{b}}$ & $1.262 \pm 0.01^{\mathrm{a}}$ & $1.376 \pm 0.04^{\mathrm{c}}$ \\
$28^{\text {th }}$ day & $1.372 \pm 0.06^{\mathrm{b}}$ & $1.336 \pm 0.01^{\mathrm{a}}$ & $1.432 \pm 0.03^{\mathrm{c}}$ \\
$35^{\text {th }}$ day & $1.678 \pm 0.08^{\mathrm{b}}$ & $1.598 \pm 0.01^{\mathrm{a}}$ & $1.848 \pm 0.05^{\mathrm{c}}$ \\
$42^{\text {nd }}$ day & $1.795 \pm 0.07^{\mathrm{b}}$ & $1.720 \pm 0.02^{\mathrm{a}}$ & $1.940 \pm 0.04^{\mathrm{c}}$ \\
\hline
\end{tabular}

The means bearing different superscripts in rows differ significantly ${ }^{\star}$ $(P<0.05)$.

concluded that diet supplementation with 12 per cent CGM showed the lowest feed intake among the experimental groups which results the lowest FCR in the commercial broilers and this result in contrast with result of Peter et al. (2000).

\section{CONCLUSION}

The study concluded that $10 \%$ CGM in feed of commercial broiler chickens can be ideally improved broiler weight gain, feed consumption and FCR. The findings of the study would be helpful for feed technologist in formulating feed for profitable broiler farming.

\section{ACKNOWLEDGEMENT}

The authors sincerely acknowledge the facilities provided by the Director, Central Poultry Development Organization and Training Institute, Bangalore for carrying out this research study.

\section{REFERENCES}

BIS. (2007). Indian Standard Poultry Feeds Specifications. $5^{\text {th }}$ Revision, IS: 1374, Manak Bhavan, 9, Bahadur Shah Zafer Marg, New Delhi. p.7.

Harper, A.E. (1964). Amino Acid Imbalance. Vol II. In Mammalian Protein Metabolism. (H.N. Munro, J.B. Allison) Academic Press. New York, NY. Pages. 87-134.

Ismail, M., Memon, A., Solagi, A.A., Ansari, N.N. and Rind, M.I. (2005). Effect of different levels of maize gluten meal on the growth performance of broiler chicks. Journal of Animal and Veterinary Advances. 4(1): 377-380.

Kim, E.J., Utterback, P.L. and Parsons, C.M. (2012). Comparison of amino acid digestibility coefficients for corn, corn gluten meal, and corn distillers dried grains with soluble among 3 different bioassays. Poultry Science. 91: 3141-3147.

Koreleski, J. (2003). An attempt to increase nutritional efficiency of diet in the first days of broiler chickens life. rocznikinaukowe. Zootechniki. 30: 121-132.

Leeson, S. and Summers, J.D. (2005). Ingredient Evaluation and Diet formulation Page 41 in: Commercial Poultry Nutrition. University Books, Guelph, ON, Canada.

Peng, Y., Tews, J.K. and Harper, A.E. (1972). Amino acid imbalance. Protein intake and changes in rat brain and plasma amino acids. American Journal of Physiology. 222: 314-321.

Peter, C.M., Han, Y., Boling-Frankenbach, S.D., Parsons, C.M. and Baker, D.H. (2000). Limiting order of amino acids and the effects of phytase on protein quality in corn gluten meal fed to young chicks. Journal of Animal Science. 78: 2150-2156.

Rose, S.P., Pirgozliev, V.R., Courtney, J. and Hare, S.D. (2003). Dietary protein sources and lysine balance on the efficiency of energy utilisation in broiler chickens. Publication-European Association for Animal Production. 109: 227-230.

Sasse, C.E. and Baker, D.H. (1973). Availability of sulphur amino acids in corn and corn gluten meal for growing chicks. Journal of Animal Science. 37: 1351-1355.

Seyedi, A.H. and Ali H.k. (2014). Evaluation corn gluten meal nutritive value for broiler chicks, International Journal of Advance Biological and Biomedical Research. 2(9): 2609-2615.

Silva, J.H., Silva, V.M.B., Silva, E.L., Jordao, F., Riberio, J., Costa, M.L.G. and Dutra, W.M. (2003). Metabolizable energy of feedstuffs determined in broiler. Revitabrasileria de Zootecnia. 32: 1912-1918.

Waldrop, P.W. (2000). Present status of the use of digestible amino acid values in formation of broiler diets: opportunities and obstacles. Asian-Australian Journal of Animal Sciences. 8: $76-87$. 